The University of Southern Mississippi

The Aquila Digital Community

Faculty Publications

6-1-2007

\title{
Music and the Making of the New South
}

Chris J. Goertzen

University of Southern Mississippi, Christopher.Goertzen@usm.edu

Follow this and additional works at: https://aquila.usm.edu/fac_pubs

Part of the Music Commons

\section{Recommended Citation}

Goertzen, C. J. (2007). Music and the Making of the New South. Journal of American Folklore, 120(477), 372-373.

Available at: https://aquila.usm.edu/fac_pubs/1988

This Book Review is brought to you for free and open access by The Aquila Digital Community. It has been accepted for inclusion in Faculty Publications by an authorized administrator of The Aquila Digital Community. For more information, please contact Joshua.Cromwell@usm.edu. 
hearing the opinion of a very small minority. That nit having been picked, I do not hesitate to recommend this book for anyone with an interest in ethnic culture in America.

Music and the Making of the New South. By Gavin James Campbell. (Chapel Hill: University of North Carolina Press, 2004. Pp. xiii + 222, acknowledgments, 29 photographs and illustrations, bibliography, index.)

\section{Chris Goertzen}

University of Southern Mississippi

The precipitous speed of social change in the United States at the turn of the twentieth century rattled Americans of all classes, races, and walks of life. In Atlanta, as Gavin James Campbell explains in his engaging Music and the Making of the New South, citizens coped with their uneasiness in part through their engagement with and their varying responses to three major annual musical events: visits by the New York Metropolitan Opera, the home-grown Colored Music Festival, and the Georgia OldTime Fiddlers' Convention. Only the last-mentioned of these events has previously attracted much attention by scholars, so not only Campbell's analyses but even his descriptions of events are of interest, offering case studies of the musical institutions and their psychological uses.

In this era, marked in the New South by the entrepreneurial zeal of Reconstruction and by Jim Crow statutes, immigration from countryside to city burgeoned in connection with industrialization and rapid growth of all sorts. Tensions between races, socioeconomic classes, and genders channeled broad trends towards economic and educational betterment. Campbell argues that groups of citizens in Atlanta sought or scorned amelioration in characteristic ways. Annual weeklong visits by the New York Metropolitan Opera Company inspired comprehensive, near-hysterical newspaper coverage, a city clean-up, social activities, and a general feeling of high-toned festival. Affluent white women supported the opera (and other art music institutions and events), in part through clubs, which helped lessen isolation in the home but which might also (to the dismay of city fathers) support women's suffrage. Their husbands were required by informal but strict rule to dodge creeping effeminacy by giving evidence of boredom with or mild hostility toward the opera and other art music concerts, but they could nevertheless support the opera as a stimulant to business and as fodder in competition between cities for cultural prestige. Blacks were not allowed to buy tickets.

The Colored Music Festival proved more fragile, not lasting long after a leading organizer left town. An impressive roster of black stars and ensembles performed pieces in both classical genres and spirituals, but whites (who were invited, indeed having their own section of seats) chose to celebrate only the spirituals. They saw spirituals as "authentic," demonstrating a comfortingly separate black culture and symptomatic of a nostalgia that they considered to be shared by both races, while blacks interpreted both their own participation in classical music and the formal and progressive nature of many performances of spirituals as evincing a stake in the ameliorative gilding of the New South.

Many who attended the Georgia Old-Time Fiddling Contest (an annual event from 1913 up to the Great Depression) were recent arrivals in Atlanta from rural areas, but plenty of wealthy white businessmen and other civic leaders enjoyed themselves there too. Campbell claims a degree of surprise that many city boosters loved the rustic events, but I am not sure why that should be the case. These prosperous white men were required by their collective masculinist code to be nervous in the presence of art music, but fiddling was rollicking fun, innocent of insidious intellectual overtones. And the social uses of this music were varied. It was not only whites fiddling, but the right whites-that is, Anglo-Saxons rather than unwashed immigrants, country folk whose women were thought to cleave to traditional roles. The fiddlers themselves, however, had mixed feelings about the homespun, rough-hewn caricatures that the papers claimed they embodied. Some fiddlers did match this image, some were good-naturedly (or cynically) will- 
ing to go along with it, but others saw fiddling as an art form.

Campbell's writing is colorful and light on jargon. This book, a reworked dissertation, retains the virtues and flaws of the parent genre. Documentation-mostly quotations from Atlanta's newspapers of the era-is stunningly thorough and quite entertaining, but the tight focus characteristic of dissertation research allowed little comparison with how the social, racial, and gender tensions at the core of the book worked out elsewhere in the country. And the newspapers so meticulously mined for the book remain newspapers, with reporters' inclinations towards simplification and hyperbole in the service of entertaining while edifying. Still, all in all, this remains a fine book. Being easy to read and not very long, it would make a nice entry in course syllabi. Other scholars studying how the tensions that Campbell explores for Atlanta were worked out elsewhere will find this book to be a ready partner.

The Bowie Knife: Unsheathing an American Legend. By Norm Flayderman. Fwd. by James S. Hutchins. (Lincoln, R.I.: Andrew Mowbrey Inc., 2004. Pp. 512, illustrations, bibliography, index.)

\section{Nathan E. Bender \\ University of Idaho}

Norm Flayderman's vast experience as an antique arms dealer and historic weapons expert (Flayderman's Guide to Antique American Firearms ... and Their Values, 8th ed., Iola, WI: Krause Publications, 2001) has allowed him to use his ties to both collectors and scholars to produce a massive, copiously illustrated book that clarifies the history of Bowie knives in general and the development of legends surrounding blacksmiths James Black and James and Rezin Bowie in particular. Flayderman's connections to the world of collectors have allowed him to select some of the finest and most representative examples of Bowie knives imaginable, making the visual aspect of the book stand head and shoulders above previous works on the topic. A first glance may be deceptive, as the extraordi- nary full color photography by Massis J. Boujikian and Rick Oltmans is so lush that it gives the work the appearance of a coffee table picture book. In the photographs, the knives are often posed decoratively on historic documents, artwork, or even fine firearms. On closer examination, it becomes evident that the lighting and printing are superb, making the knives, and often their sheaths, clearly visible for those interested in details of construction or stylistic elements. Full captions for each picture often provide dimensions and inscriptions. Vintage nineteenthcentury photographs of persons wearing or displaying Bowie knives are also used to excellent effect.

However, it is Flayderman's historic overview and well-informed discussion that instantly make this book the authoritative text on the topic. Flayderman goes to great lengths to document the growth of the Bowie legend, showing its many embellishments and distortions over time. The interplay of popular print culture and the development of a body of common folklore that developed into a great American legend is largely detailed through the research and writings of Raymond Thorp, one of the most creative and influential students of the Bowie knife. Flayderman examines Thorp's 1948 book The Bowie Knife (University of New Mexico Press) to reveal in it a strong pattern of misrepresented historical accounts, rewritten material, and even newly written material represented as authentic history or oral tradition. Examples of ideas in Thorp's book based on highly questionable or even fictitious sources are "schools of Bowie knife fighting" supposedly located throughout the nineteenth-century American West and formal Bowie knife duels conducted according to European codes of honor (pp. 312, 481-4). Revisiting Thorp's book is a valuable service. Even though many people already regard Thorp's writings as highly suspect, it is helpful that Flayderman conscientiously validates the general concern. Flayderman also shows how Thorp's writing influenced others, allowing for further research into the ways in which exciting and entertaining popular accounts grow to become generally accepted and influential American legends.

Discussions of Bowie knives as material cul- 